\title{
PROFESOR DR HAB. JERZY HAUZIŃSKI (1946-2020)
}

24 grudnia 2020 roku zmarł Profesor Jerzy Hauziński, wybitny orientalista i bałkanista, badacz średniowiecza, pedagog i wychowawca młodzieży.

Profesor Jerzy Hauziński urodził się w Poznaniu, gdzie przeszedł wczesne etapy edukacji. W latach 1966-1970 odbył studia historyczne na Uniwersytecie Adama Mickiewicza. Wcześnie zainteresował się mediewistyką i wkrótce znalazł się w kręgu uczniów prof. Gerarda Labudy, pod którego kierunkiem pisał prace magisterską i doktorską. Zafascynowany orientem w latach 1972-1973 oraz ponownie w 1977 roku odbywał staż w Instytucie Filologii Orientalnej Uniwersytetu Jagiellońskiego, gdzie zaznajamiał się z językiem i kulturą arabską pod opieką naukową prof. Tadeusza Lewickiego. Znajomość języków orientalnych wykorzystał w obronionej w 1973 roku pracy doktorskiej pt. „Asasyni - radykalny ruch społeczno-polityczny muzułmańskiego średniowiecza w europejskim piśmiennictwie wieków średnich”. W 1977 roku uzyskał na Wydziale Historycznym UAM stopień doktora habilitowanego na podstawie rozprawy pt. „Polityka orientalna Fryderyka II Hohenstaufa”. Książka W kręgu uniwersalizmu średniowiecznego „, Sacrum Imperium Romanum " i załamanie niemieckiej polityki imperialnej w pierwszej połowie XIII wieku stała się podstawą do nadania w 1989 roku Jerzemu Hauzińskiemu tytułu profesora.

Profesor Jerzy Hauziński wykładał na kilku krajowych uczelniach: Uniwersytecie Adama Mickiewicza w Poznaniu, Uniwersytecie Wrocławskim, Uniwersytecie Gdańskim, Uniwersytecie Jagiellońskim w Krakowie oraz Wyższej Szkole Inżynierskiej w Koszalinie. Na stałe związał się jednak z Pomorską Akademią Pedagogiczną w Słupsku (wcześniej Wyższa Szkoła Pedagogiczna), gdzie od 1992 roku zajmował stanowisko profesora zwyczajnego. W słupskiej uczelni prof. Jerzy Hauziński pełnił ważne funkcje: w latach 1990-1995 był dziekanem Wydziału Humanistycznego, w okresie 1996-1998 - dyrektorem Instytutu Historii, a w latach 1997-2002 piastował stanowisko rektora. W 2016 roku Profesor przeszedł na emeryturę. Współpracownicy, koledzy i przyjaciele podczas uroczystości jubileuszowej ofiarowali mu obszerny zbiór studiów: Na szlakach dwóch światów (Słupsk 2016).

W liczącej ponad 150 pozycji bibliografii prof. Jerzego Hauzińskiego znaleźć można ogromnie zróżnicowane prace: monografie, rozprawy, artykuły, recenzje i omówienia w językach: polskim, arabskim, angielskim, niemieckim i czeskim. Zdecydowana większość z nich dotyczy kultury i religii krajów szeroko pojętego orientu i relacji muzułmańsko-chrześcijańskich w średniowieczu, ale zainteresowania badawcze Profesora obejmowały znacznie bardziej rozległy obszar geograficzny 
i sięgały od średniowiecza do czasów najnowszych. Szczególną uwagę poświęcał w badaniach sekcie asasynów (od badania których zaczął swą karierę naukową i którym poświęcił swą ostatnią monografię!) oraz ismaelickiej sekcie nizarytów. Na podkreślenie zasługuje również zainteresowanie badawcze Profesora dziejami państwa Osmanów i obszarami Bałkanów będących pod ich wpływem.

Wśród najważniejszych książek napisanych przez prof. Jerzego Hauzińskiego należy wymienić: Muzutmańska sekta asasynów w europejskim piśmiennictwie wieków średnich (Poznań 1978), Burzliwe dzieje kalifatu bagdadzkiego (Warszawa-Kraków 1993), Imperator końca świata Fryderyk II Hohenstauf 1194-1250 (Gdańsk 2000), Tropem muzutmańskich dziejów (Toruń 2007), Fryderyk II Hohenstauf, cesarz rzymski (Poznań 2015), Asasyni. Legendarni zabójcy w czasach krucjat (Poznań 2016).

Profesor był współautorem kilku prac o charakterze monograficznym i syntetycznym, między innymi: Historii Albanii (z Janem Leśnym, Wrocław 1992; oraz wyd. 2 zmienione z Tadeuszem Czekalskim, Wrocław 2009), Wielkiej Historii Świata, t. V (Kraków 2004), Muzutmanów w Europie (Warszawa 2004), Historii Iranu (Wrocław 2010). Na szczególną uwagę zasługują dwa zbiory źródeł z obszaru orientu: Islam $w$ feudalnych państwach arabskich i krajach ościennych (Poznań 1976) oraz Kraje i kultury śródziemnomorskie (Poznań 1990).

Prof. Jerzy Hauziński angażował się w życiu naukowe. Od 1988 roku był członkiem Komitetu Nauk Orientalistycznych Polskiej Akademii Nauk, a w latach 2003-2006 wiceprzewodniczącym tegoż Komitetu. Należał do założycieli Komisji Bałkanistyki Oddziału Poznańskiego PAN, a w okresach 1991-2003 i 2007-2011 piastował funkcję wiceprzewodniczącego tej komisji. Był członkiem rad redakcyjnych kilku krajowych czasopism, między innymi „Balcanica Posnaniensia. Acta et Studia”, „Studia Arabistyczne i Islamistyczne” oraz „Orientalia Christiana Cracoviensia".

Prof. Jerzy Hauziński był oddanym młodzieży nauczycielem akademickim. Pełnił funkcję recenzenta w 18 przewodach habilitacyjnych i był autorem 24 recenzji doktorskich. Niezwykle aktywny na polu dydaktycznym obok wielu prac magisterskich wypromował siedmioro doktorów.

W uznaniu zasług prof. Jerzy Hauziński w 2002 roku został odznaczony Krzyżem Kawalerskim Orderu Odrodzenia Polski.

Wraz z odejściem prof. Jerzego Hauzińskiego polska humanistyka straciła wielkiego uczonego, badacza i nauczyciela. Ci, którzy znali go bliżej, utracili wspaniałego Kolegę, zawsze pełnego pogody ducha i życzliwości.

Piotr Wróbel (D) http://orcid.org/0000-0002-1332-4181

Uniwersytet Jagielloński w Krakowie Adres do korespondencji: piotr.wrobel@uj.edu.pl 